\title{
OCCURRENCE OF DIPSACUS STRIGOSUS (CAPRIFOLIACEAE) IN HUNGARY
}

\author{
T. WIRTH* and J. CSIKY \\ Department of Ecology, University of Pécs, \\ H-7624 Pécs, Ifjúság útja 6, Hungary; *tamaswirth@gmail.com
}

Wirth, T. \& Csiky, J. (2019): Occurrence of Dipsacus strigosus (Caprifoliaceae) in Hungary. - Studia bot. hung. 50(2): 357-364.

\begin{abstract}
During the systematic flora survey of the city a large stand of Dipsacus strigosus was found in Pécs. Morphological characteristics, some phytocoenological features, the most likely way of introduction, and the expansion dynamics are discussed and a new key to the Dipsacus taxa of Hungary is presented in the study.
\end{abstract}

Key words: adventive species, ruderal vegetation, stream bank, urban flora

\section{INTRODUCTION}

Since the flora of urban areas is usually more rich in species than the flora in their environment (ARAÚJO 2003, KÜHN et al. 2004), and in most cases human activities are mainly responsible for long distance dispersal, large amount of neophytes appear the first time and are going through naturalisation in urban habitats (e.g. BÁtori et al. 2012, Wolf \& KirÁly 2014). The family Dipsacaceae is represented by 6 genera in the Hungarian flora (KIRÁLY 2009). One of them, Dipsacus L. is an old world genus with species distributed mainly in Eurasia and Northern Africa. Only three of them (D. fullonum L., D. laciniatus, and D. pilosus L.) are native to Hungary (KirÁly 2009, Simon 2000, Soó 1966). The indigenous members of the genus occur mostly in naturally disturbed or anthropogenic habitats. D. strigosus Willd. ex Roem. et Schult. is native to Ukraine, southern Russia, and western Asia (Ahrens 2008, Hansen 1976, Domina 2017) and introduced/more or less naturalised elsewhere in Europe (AHRENS 2007, 2008, Danihelka et al. 2012, Domina 2017, Hansen 1976, Leslie 1976, 1980, Melzer \& Barta 2002, Pagitz 2008, Poelt 1976, Romahn 2010, VerLOOVE 2018). During the systematic flora survey of the administrative area of Pécs (Hungary) a large population of $D$. strigosus was found along the bank of a stream (that takes its source from Lake Balokány, close to the city centre) in 2013. Including the newly established $D$. strigosus the authors provide a new key to the recent Hungarian Dipsacus taxa (KIRÁLY 2009). Furthermore, the possible 
way of occurrence and some phytosociological features of the newly established Dipsacus species are also given in this paper.

\section{MATERIAL AND METHODS}

The field study was conducted in the summer of 2013. The specimens were identified using the key of VerLOOVE (2018). To characterise the habitat of $D$. strigosus, coexisting species were listed in five $4 \mathrm{~m}^{2}$ plots according to the BraunBlanquet methodology (LÁJER et al. 2007). Compilation of the analytical table and calculation of species frequencies were managed in the JUICE program (TICHÝ 2002). To identify the characteristic species of the syntaxonomic classes the authors used the 'EuroVegChecklist Expert System' tool embedded within the software of JUICE (MUCINA et al. 2016). Latitude and longitude coordinates and elevations of the sites were determined with GPS in WGS 84 projection. The identification and nomenclature of the accompanying species are based on and follow KIRÁLY (2009). Herbarium specimens were also collected and vouchers were placed in the Herbarium of the University of Pécs (JPU). Quadrate number is given according to the Hungarian Flora Mapping Programme (BARThA et al. 2015).

\section{RESULTS AND DISCUSSION}

Dipsacus strigosus is a tall (up to $200 \mathrm{~cm}$ ), biennial herb. The stems are erect, sparsely prickly and hispid. Basal leaves are in a rosette, ovate, narrowed to a long petiole. The cauline leaves are shortly petiolate, not connate at base, ovate-elliptical, with a basal pair of unequal, elliptical leaflets, sometimes simple. Capitula is $20-40 \mathrm{~mm}$ in diameter, globose. Involucral bracts are narrowly triangular, sparsely white hispid, with apical spine. The receptacular scales are 15-20 mm long, long attenuate, ciliate, but glabrous at apex. Corolla is pale yellow, anthers yellow or greenish-yellow. Achenes are 4-4.5 mm long, greyish-brown, with black streaks (Ahrens 2007, Poelt 1970, Verloove 2018) (Fig. 1).

Besides the 13 native and two casual neophyte species of the subfamily, this is the first adventive representative considered to be established of Dipsacoideae in the Hungarian flora (BALOGH et al. 2004, KIRÁLY 2009). The relatively large stand of D. strigosus was found in Pécs, along the southern bank of the stream rise from Lake Balokány, in the [9975/1] Hungarian Flora Mapping Unit (Fig. 2) (BARTHA et al. 2015). The number of individuals was unstable over the last few years: the initial number of individuals has declined from tens of thousands to a few thousand specimens (this could be attributed to the dredging of the streambed and the placement of dredge on the plants, and with the irregular mowing of the stream bank), however the species spread a few hundreds of metres (at a 

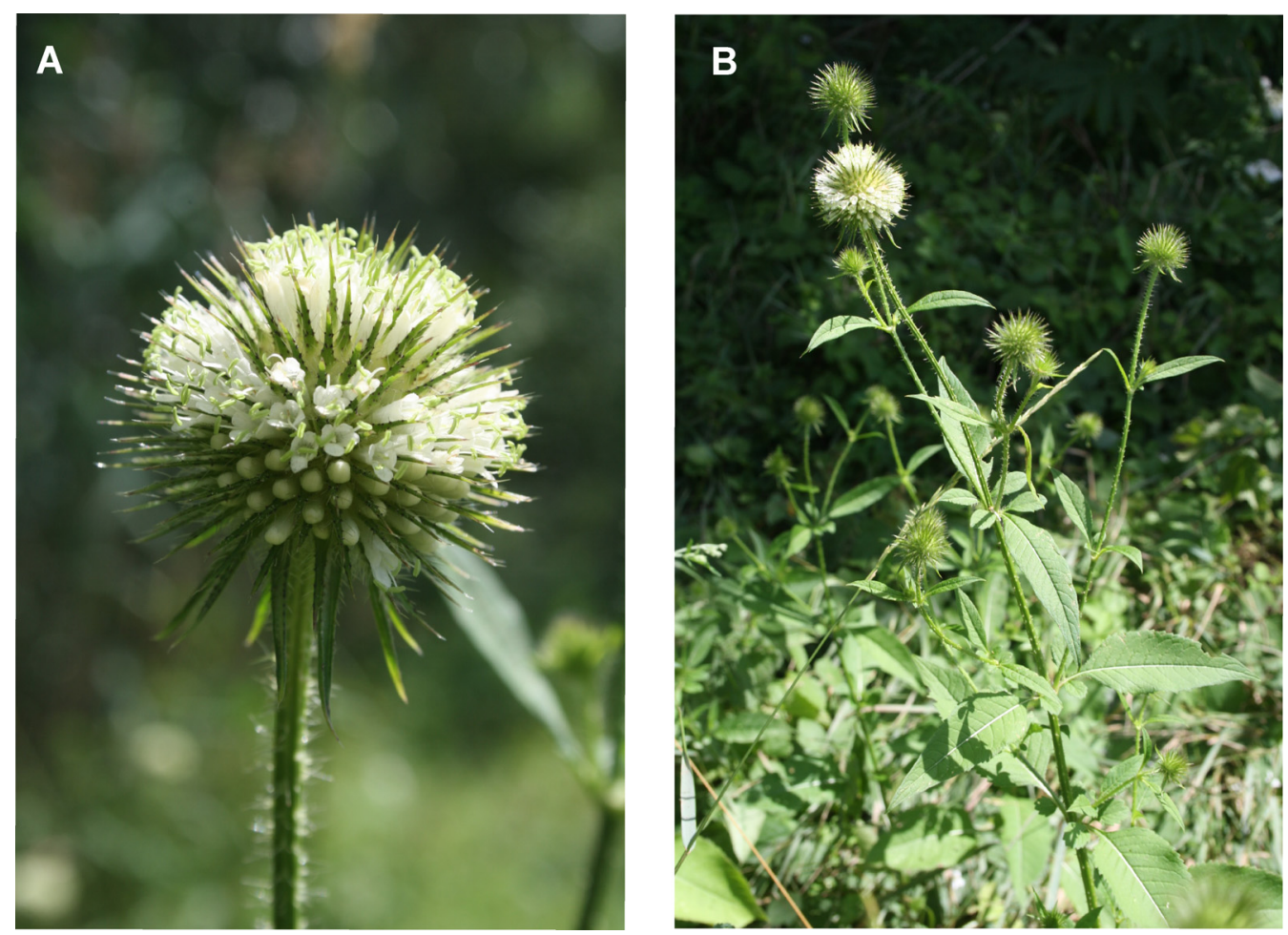

Fig. 1. Flowering head (A) and habit (B) of Dipsacus strigosus (photos by T. Wirth).

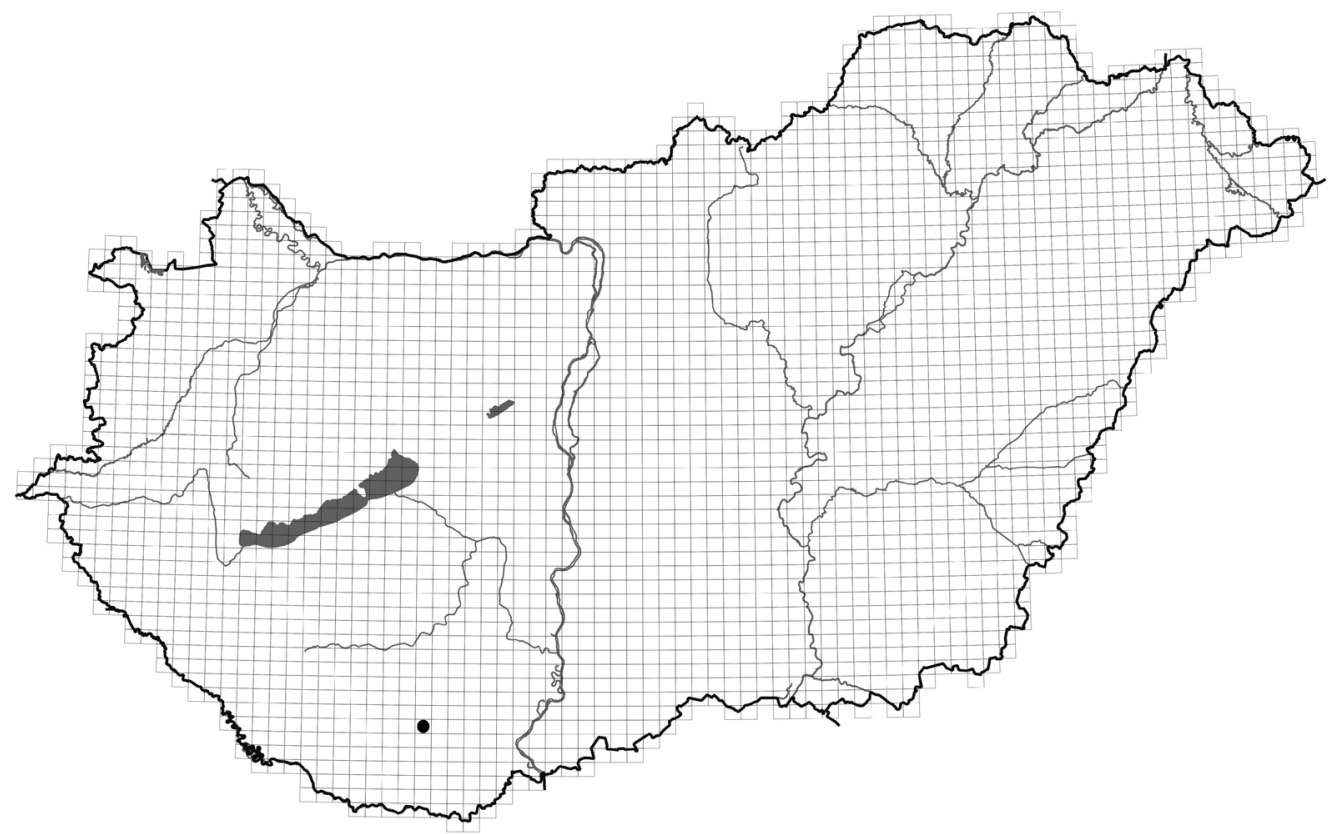

Fig. 2. Distribution of Dipsacus strigosus Willd. ex Roem. et Schult. in Hungary. 
speed of 52 metres/year) along the creek downstream over the year of detection. This expansion could be explained by hydrochory (spread by floods) and by epizoochory, due to the high density of big game species (e.g. wild boars, European roe deers) occurring in this part of the city.

The species originally grows in thickets of shady places (BOBROv 1976) and it has been indicated from mesic/wet woodlands and from tall-herb vegetation on raw alluvia of colline-submontane streams (alliance: Petasition officinalis Sillinger 1933) out of its native range (Medvecká et al. 2012, Poelt 1970, Verloove 2011). In Hungary, D. strigosus occurs in a narrow band of ruderal tall-herb vegetation between the recultivated tailings reservoir (planted with willow and poplar species) of the Pécs thermal power plant and the stream rise from Lake Balokány. This habitat is dominated by a mixture of some common, nitrophilous and weedy plants characteristic for roadsides and alluvial forest fringes (for further details see Table 1).

Table 1. Synthetic table of the stand of $D$. strigosus in Pécs, along the southern bank of the stream from Lake Balokány. Abbreviations: Fr-frequency (relevés made by T. Wirth and J. Csiky on the 17 th of July, 2013).

\begin{tabular}{|c|c|c|c|c|c|c|}
\hline Relevé number & 1 & 2 & 3 & 4 & 5 & $\mathrm{Fr}$ \\
\hline Plot size $\left(\mathrm{m}^{2}\right)$ & 4 & 4 & 4 & 4 & 4 & \\
\hline Latitude $\left({ }^{\circ}\right)$ & 46.07157 & 46.07251 & 46.07253 & 46.07293 & 46.07307 & \\
\hline Longitude $\left({ }^{\circ}\right)$ & 18.24409 & 18.24508 & 18.24516 & 18.24553 & 18.24555 & \\
\hline Elevation (m) & 127 & 127 & 127 & 127 & 127 & \\
\hline E1 layer (\%) & 100 & 100 & 100 & 100 & 100 & \\
\hline E0 layer (\%) & 10 & + & 5 & 5 & + & \\
\hline Ballota nigra & + & 1 & $\mathrm{r}$ & $\mathrm{r}$ & 1 & 5 \\
\hline Dipsacus strigosus & 2 & 3 & 3 & 4 & 3 & 5 \\
\hline Rubus caesius & 3 & 5 & 1 & 1 & 4 & 5 \\
\hline Agrostis stolonifera & 1 & + & & + & $\mathrm{r}$ & 4 \\
\hline Elymus repens & 2 & 1 & 2 & 2 & & 4 \\
\hline Medicago lupulina & 1 & + & & 1 & + & 4 \\
\hline Melilotus albus & + & & + & 1 & 1 & 4 \\
\hline Urtica dioica & 2 & $\mathrm{r}$ & + & & + & 4 \\
\hline Calystegia sepium & 1 & $\mathrm{r}$ & & $\mathrm{r}$ & & 3 \\
\hline Phalaris arundinacea & & + & & 1 & + & 3 \\
\hline Ambrosia artemisiifolia & & & & + & + & 2 \\
\hline Arctium lappa & 2 & & & 2 & & 2 \\
\hline Artemisia vulgaris & $\mathrm{r}$ & & $\mathrm{r}$ & & & 2 \\
\hline Bromus sterilis & & + & & & $\mathrm{r}$ & 2 \\
\hline
\end{tabular}


Table 1 (continued)

\begin{tabular}{|c|c|c|c|c|c|c|}
\hline Relevé number & 1 & 2 & 3 & 4 & 5 & $\mathrm{Fr}$ \\
\hline Chelidonium majus & & & & $\mathrm{r}$ & $\mathrm{r}$ & 2 \\
\hline Erigeron annuus & + & & & $\mathrm{r}$ & & 2 \\
\hline Geum urbanum & + & + & & & & 2 \\
\hline Humulus lupulus & + & & + & & & 2 \\
\hline Melilotus officinalis & & & & + & + & 2 \\
\hline Picris hieracioides & & & $\mathrm{r}$ & $\mathrm{r}$ & & 2 \\
\hline Plantago major & & $\mathrm{r}$ & & & $\mathrm{r}$ & 2 \\
\hline Sambcucus ebulus & & 2 & 2 & & & 2 \\
\hline Tanacetum vulgare & 1 & & & & 1 & 2 \\
\hline Torilis arvensis & & 1 & + & & & 2 \\
\hline Torilis japonica & & & & $\mathrm{r}$ & $\mathrm{r}$ & 2 \\
\hline Trifolium pratense & & & & + & 1 & 2 \\
\hline Trifolium repens & $\mathrm{r}$ & & & + & & 2 \\
\hline Tripleurospermum perforatum & $\mathrm{r}$ & & & $\mathrm{r}$ & & 2 \\
\hline Calamagrostis epigeios & + & & & & & 1 \\
\hline Carduus acanthoides & & & & & + & 1 \\
\hline Carex spicata & $\mathrm{r}$ & & & & & 1 \\
\hline Cirsium arvense & & & & $\mathrm{r}$ & & 1 \\
\hline Conyza canadensis & $\mathrm{r}$ & & & & & 1 \\
\hline Cornus sanguinea & $\mathrm{r}$ & & & & & 1 \\
\hline Cucubalus baccifer & & & & $\mathrm{r}$ & & 1 \\
\hline Dactylis glomerata & $\mathrm{r}$ & & & & & 1 \\
\hline Dipsacus laciniatus & 1 & & & & & 1 \\
\hline Eupatorium cannabinum & & & & 1 & & 1 \\
\hline Juglans regia & $\mathrm{r}$ & & & & & 1 \\
\hline Lactuca serriola & & & & & $\mathrm{r}$ & 1 \\
\hline Linaria vulgaris & $\mathrm{r}$ & & & & & 1 \\
\hline Papaver rhoeas & & & & & $\mathrm{r}$ & 1 \\
\hline Parthenocissus inserta & & & $\mathrm{r}$ & & & 1 \\
\hline Poa pratensis & + & & & & & 1 \\
\hline Potentilla indica & $\mathrm{r}$ & & & & & 1 \\
\hline Prunus cerasifera & & $\mathrm{r}$ & & & & 1 \\
\hline Silene alba & & & + & & & 1 \\
\hline Sonchus oleraceus & & & & & $\mathrm{r}$ & 1 \\
\hline Taraxacum officinale & & $\mathrm{r}$ & & & & 1 \\
\hline Verbascum blattaria & & & $\mathrm{r}$ & & & 1 \\
\hline Vicia grandiflora & & & & & $\mathrm{r}$ & 1 \\
\hline
\end{tabular}


According to the descriptions of Borhid et al. (2012) and Mucina et al. (2016) this vegetation type presumably belongs to the syntaxonomic class Artemisietea vulgaris Lohm. et al. in Tüxen 1950, which contains associations of nitrophilous weed vegetation of roadsides. Despite the fact that the local vegetation is similar to the preferred habitat of D. strigosus (BOBROV 1976, MEDVECKÁ et al. 2012), the relatively high stream bank (deep stream-bed) and mowing may be responsible for conditions similar to roadside habitats.

The authors firmly suggest the insertion of $D$. strigosus in the Hungarian Dipsacus key (KIRÁLY 2009) as follows:

1a Cauline leaves shortly petiolate, not connate at base. Inflorescence glo-

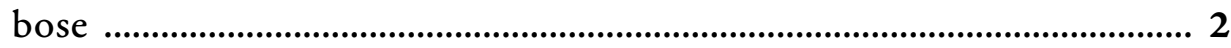

1b Cauline leaves sessile, connate at base. Inflorescence ovoid-cylindrical .... 3

2a Capitula 15-20 $\mathrm{mm}$ in diameter. Corolla white, anthers dark purplish to blackish. Receptacular scales hardly longer than corolla, 8-12 mm long, abruptly narrowed and ciliate towards at apex. Achenes $4-5 \mathrm{~mm}$ long, conspicuously ribbed, brown D. pilosus L.

2b Capitula 25-40 $\mathrm{mm}$ in diameter. Corolla pale yellow, anthers yellow or greenish-yellow. Receptacular scales distinctly longer than corolla, 15-20 $\mathrm{mm}$ long, long attenuate and glabrous at apex. Achenes $4-4.5 \mathrm{~mm}$ long, ribs inconspicuous, greyish-brown, with black stripes

D. strigosus Willd. ex Roem. et Schult.

3a Cauline leaves deeply lobed or pinnatisect, prickly and hispid. Involucral bracts widest at the base, \pm spreading, hardly longer than the inflorescence. Corolla whitish or pale pink

D. laciniatus L.

3b Cauline leaves entire, usually with entire margin, glabrous or sparsely hispid. Involucral bracts linear, ascending, usually longer than the inflorescence. Corolla bluish purple

D. fullonum L.

There is no previous information on the occurrence of $D$. strigosus in Hungary. In Pécs the plants grows next to an industrial site and a former railway dock, therefore the possible ways of introduction could have been the followings: i) transport by trains, ii) previous landscaping and earthworks, iii) cultivation of non-native aquatic and wetland species in Lake Balokány.

Since the species can be easily confused with the indigenous $D$. pilosus, plants with globose inflorescence appearing in unusual habitats (urban habitats, wastelands, etc.) should be taken with caution in Hungary in the future (see comments of VerLOOVE 2011). The invasiveness of $D$. strigosus is controversial (Ahrens 2008, PyšEK et al. 2012, Verloove 2018) - at the moment it seems to be a rather weedy/invasive species. The cultivation and usage as an ornamental is 
not typical, but due to its increasing expansion in Central and Western Europe, future monitoring may be important in Hungary.

Acknowledgements - The project was supported by the European Union, and co-financed by the European Social Fund: Comprehensive Development for Implementing Smart Specialization Strategies at the University of Pécs (EFOP-3.6.1.-16-2016-00004).

Összefoglaló: A szerzők Pécs flórájának szisztematikus felmérése során, 2013-ban egy hazánkból eddig nem ismert mácsonyafaj több tízezer egyedet számláló állományára bukkantak a város Balokány nevủ részén, a pécsi hőerőmű korábban rekultivált zagytározója és a Balokány-tóból kiinduló patak közötti sávban. A Dipsacus strigosus Ukrajnából, Dél-Oroszországból és Nyugat-Ázsiából származó, Nyugat- és Közép-Európában már hosszabb ideje terjedő, illetve meghonosodott adventív faj. A faj hazai megtelepedésével kapcsolatban nincsenek pontos információink, de a termőhely helyzete alapján a behurcolás történhetett a vasúti közlekedés és az ezzel kapcsolatos karbantartási munkálatok, esetleg a korábbi földmunkák által, vagy a Balokány-tóba meghonosított vízi- és mocsári növények telepítése során. A D. strigosus könnyen összetéveszthető a Magyarországon őshonos és hasonló termőhelyi körülmények között előforduló $D$. pilosus L.-el, ezért a szerzők indokoltnak tartották a hazai Dipsacus határozó kulcs kiegészítését. A faj eredeti elterjedési területén árnyas cserjésekben fordul elő, meghonosodott állományait pedig nedves erdőkből, illetve dombvidéki patakparti magaskórósokból jelezték. A magyarországi állomány hasonló körülmények között, de inkább az útszéli gyomnövényzethez közelebb álló élőhelyen fordult elő. Bár a termőhely zavarása miatt a növényegyedek száma a megtalálás évétől kezdve erősen fluktuált, a faj mégis több száz métert terjedt folyásirányban a patak mentén. Gyors expanziója miatt a $D$. strigosus monitorozása erősen ajánlott.

\section{REFERENCES}

Ahrens W. (2007): Zur Unterscheidung von Dipsacus pilosus L. und Dipsacus strigosus Willdenow ex Roemer et Schultes. - Mitt. florist. Kart. Sachsen-Anhalt 12: 71-75.

Ahrens W. (2008): Dipsacus strigosus Willdenow ex Roemer et Schultes 1818. Eine neue Sippe in Niedersachsen. - Braunschweiger Geobot. Arbeit. 9: 21-41.

ARAújo M. B. (2003): The coincidence of people and biodiversity in Europe. - Global Ecol. Biogeogr. 12: $5-12$.

Bartha D., Király G., Schmidt D., Tiborcz V., Barina Z., Csiky J., Jakab G., Lesku B., Schmotzer A., Vidéki R., Vojt kó A. \& Zólyomi Sz. (eds) (2015): Distribution atlas of vascular plants of Hungary. - University of West Hungary Press, Sopron, $330 \mathrm{pp}$.

BÁtori Z., ERDős L. \& Somlyay L. (2012): Euphorbia prostrata (Euphorbiaceae), a new alien in the Carpathian Basin. - Acta Bot. Hung. 54(3-4): 235-243.

Bobrov E. G. (1976): Dipsacaceae L. - In: Shish Kin B. K. \& Bobrov E. G. (eds): Flora of the U.S.S.R. Vol. XXIV. Israel Program for Scientific Translations, Jerusalem, pp. 16-20.

Borhidi A., Kevey B. \& Lendvai G. (2012): Plant communities of Hungary. - Akadémiai Kiadó, Budapest, $544 \mathrm{pp}$.

Danihelka J., Chrtek J. \& Kaplan Z. (2012): Checklist of vascular plants of the Czech Republic - Preslia 84(3): 647-811.

Domina G. (2017): Dipsacaceae. - In: Euro+Med Plantbase, the information resource for EuroMediterranean plant diversity. http://ww2.bgbm.org/EuroPlusMed/ [accessed 06/11/2018]. 
KirÁly G. (ed.) (2009): Új magyar füvészkönyv. Magyarország hajtásos növényei. Határozókulcsok. - ANP Igazgatóság, Jósvafo", 616 pp.

KÜHN I., BRANDL R. \& KLOTZ S. (2004): The flora of German cities is naturally species rich. Evol. Ecol. Res. 6: 749-764.

Hansen A. (1976): Dipsacus L. - In: Tutin T. G. et al. (eds): Flora Europaea 4. Cambridge University Press, Cambridge, pp. 58-59.

Lájer K., Botta-Dukát Z., Csiky J., Horváth F., Szmorad F., Bagi I., Dobolyi K., Hahn I., KovÁcs J. A. \& RÉDEI T. (2007): Hungarian phytosociological database (Coenodatref): sampling, methodology, nomenclature and its actual stage. - Annali di Bot. 7: 27-40.

Leslie A. C. (1976): Dipsacus strigosus Willd. in Cambridgeshire, v.c. 29. - Watsonia 11: 67-74.

LESLIE A. C. (1980): Further records of Dipsacus strigosus Willd. in Cambridgeshire. - Watsonia 13: $126-128$.

Medvecká J., Kliment J., Májeková J., Halada L., Zaliberová M., Gojdičová E., FeráKOVÁ V. \& JAROLÍmEK I. (2012): Inventory of the alien flora of Slovakia. - Preslia 84(2): 257-309.

Melzer H. \& Barta T. (2002): Dipsacus strigosus, die Schlanke Karde, neu für Österreich und anderes Neue zur Flora von Wien, Niederösterreich und dem Burgenland. - Linzer biol. Beitr. 34(2): 1237-1261.

Mucina L., Bültmann H., Dierssen K., Theurillat J., Raus T., Čarni A., Šumberová K., Willner W., Dengler J., Gavilán García R., Chytrý M., Hájek M., Di Pietro R., iakushenko D., Pallas J., Daniëls F. J. A., Bergmeier E., Santos Guerra A., Ermakov N., Valachovič M., Schaminée J. H. J., Lysenko T., Didukh Y. P., Pignatti S., Rodwell J. S., Capelo J., Weber H. E., Solomeshch A., Dimopoulos P., Aguiar C., HENNEKENS S. M. \& TiCHÝ L. (2016): Vegetation of Europe: hierarchical floristic classification system of vascular plant, bryophyte, lichen, and algal communities. - Appl. Veg. Sci. 19 (Suppl. 1): 3-264.

PAgitz K. (2008): Neuheiten, besonders Neophyten, in der Tiroler Flora. - Neilreichia 5: 115-129.

Poelt J. (1970): Dipsacus pilosus und sein verkannter Doppelgänger Dipsacus strigosus in Südbayern. - Ber. Bayer. Bot. Ges. 42: 203-206.

Pyšek P., Danihelka J., Sádlo J., Chrtek Jr. J., Chytrú M., Jarošík V., Kaplan Z., Krahulec F., Moravcová L., Pergl J., Štajerová K. \& TichÝ L. (2012): Catalogue of alien plants of the Czech Republic (2nd edition): checklist update, taxonomic diversity and invasion patterns. - Preslia 84(2): 155-255.

RomAнN K. (2010): Funde seltener, gefährdeter, neuer und wenig beachteter Gefäßpflanzen in Schleswig-Holstein VI. - Kieler Notizen zur Pflanzenk. 37: 83-103

Simon T. (2000): A magyarországi edényes flóra határozója. Harasztok-virágos növények. - Nemzeti Tankönyvkiadó Rt., Budapest, 845 pp.

Soó R. (1966): A magyar flóra és vegetáció rendszertani-növényföldrajzi kézikönyve II. - Akadémiai Kiadó, Budapest, 655 pp.

TICHÝ L. (2002): JUICE, software for vegetation classification. - J. Veg. Sci. 13(3): 451-453.

Verloove F. (2011): Dipsacus strigosus found in Belgium and possibly overlooked. - Manual of the alien plants of Belgium. Botanic Garden of Meise, Belgium, http://alienplantsbelgium.be/ content/dipsacus-strigosus-found-belgium-and-possibly-overlooked [accessed 06.11.2018]

Verloove F. (2018): Dipsacus. - Manual of the alien plants of Belgium. Botanic Garden of Meise, Belgium, http://alienplantsbelgium.be/content/dipsacus [accessed 06.11.2018]

Wolf M. \& KirÁly G. (2014): Euphorbia serpens (Euphorbiaceae), a new alien species in Hungary. - Acta Bot. Hung. 56(1-2): 243-250.

(submitted: 18.06.2019, accepted: 20.09.2019) 